\title{
人工水平排水材を用いた空港盛土の挙動解析
}

\author{
石川県土木部 長原久克白本工営（株）鶴山直義 \\ 前田建設工業（株） 今井努 - 伊藤雅夫 - 石黒 健 - ○藤山哲雄 \\ 東京工業大学 太田秀樹
}

能登空港用地造成工事では、高含水比粘性土を高さ $55 \mathrm{~m}$ まで急速盛立する必要があることから、人 工水平排水材を用いて圧密促進を図りつつ盛立を行っている。本論文では、排水材を敷設した盛土体 の応力変形挙動や盛土の安定性を合理的に解析する手法の確立を目指し、弾粘塑性 FEM の適用性を 検討した。この結果、応力・沈下挙動は実測值と良好な整合を示し、今回用いた解析手法が盛土の応 力変形予測手法として妥当であること、しかし実測の水平変位はほとんど生じず、解析には見込まれ ていない土と排水材の摩擦による補強効果が実際には相当発揮されている可能性があること、などが わかった。

また、能登空港造成盛土を対象として、盛立施工速度や排水材の有無などの現場条件の組み合わせ によって盛土安定性が大きく変化することを試計算により示し、現場毎の材料特性や施工条件、境界 条件等を詳細に反映できる FEM 用いた合理的な水平排水材の敷設設計の可能性を示している。

キーワード：高含水比粘性土、急速盛立、人工水平排水材、弾粘塑性 FEM、挙動解析

\section{An Analysis of Airport Fill with Geotextile Horizontal Drain}

\author{
H.Nagahara : Ishikawa Prefecture N.Tsuruyama : Nihon-Koei Corporation \\ T.Imai, M.Itoh, T.Ishiguro and T.Fujiyama : Maeda Corporation \\ H.Ohta : Tokyo Institute of Technology
}

The fill of Noto Airport is constructed rapidly to a height of 55 meters, and its embankment material is high water content clay. Geotextile horizontal drain is installed in the fill to accelerate consolidation. To establish a reasonable method to analyze a behavior of the fill installed the horizontal drain, an applicability of the elasto-visco-plastic FEM is examined in this paper. The result of the simulation is agreed with observed deformation and stress behavior, but horizontal deformation measured is smaller than estimated by FEM. It probably shows that a reinforced effect by friction between the soil and the geotexitile, not modeled in FEM, is produced in fact. Some trial FEM calculations in varies case of the field conditions such as varies embankment speed are done, and a possibility of applying FEM which has the advantage of adapt to complicated conditions to the design for drain placing is shown.

Keywords : high water content clay, rapid embankment, geotextile horizontal drain, elasto-visco-plastic FEM, deformation analysis 


\title{
人工水平排水材を用いた空港盛土の挙動解析
}

\author{
石川県土木部 長原久克日本工営（株）鶴山直義 \\ 前田建設工業（株） 今井努・伊藤雅夫・石黒 健・ ○藤山哲雄 \\ 東京工業大学工学部 太田秀樹
}

\section{1 .はじめに}

能登空港用地造成工事では、盛土材の主体が自然含水比 30〜80\%の高含水比粘性土であり、これを 高さ $55 \mathrm{~m}$ まで急速盛立を行う必要があることから、人工水平排水材（ジオテキスタイル）を用いて圧 密促進を図りつつ、盛立を行っている。

近年、このような人工水平排水材を利用した高含水粘性土盛土の建設事例が増えつつあるが、本工 法の効果や盛土体の応力変形挙動、安定性を合理的に解析する手法は未だ確立されていない。そこで 本論文では、能登空港造成盛土に対し土／水連成効果を考慮した弾粘塑性 FEM 解析を実施し、実測 挙動との比較からその適用性を検証する。

また、FEM 解析のメリットとして、現場毎の材料特性や施工条件、境界条件等を詳細に反映できる ことが挙げられる。本論文では、能登空港造成盛土を対象として、盛立施工速度や排水材の有無など の現場条件の組み合わせによって盛土安定性が大きく変化することを試計算により示し、FEMを用い た水平排水材の合理的な敷設設計の可能性に言及する。

\section{2. 能登空港用地造成工事の概要}

本工事は、石川県輪島市から約 $10 \mathrm{~km}$ ほど内陸に入った丘陵地帯において、能登空港（平成 15 年開 港予定）の用地造成を行う工事である。総土工量約 1,600 万 $\mathrm{m}^{3}$ (盛土 800 万 $\mathrm{m}^{3}$ 、切土 800 万 $\mathrm{m}^{3}$ ) で 最大盛土高さ $55 \mathrm{~m}$ に及ぶ大規模土工事であるが、これを 3 年 (冬季休止期間を考慮すると実質約 2 年) という短期間で急速施工を行う必要があった。

本空港盛土の標準断面を図 1 に 示す。滑走路下を圧縮性の小さい 軟岩、法面部をせん断強度の大き い硬岩、その他のゾーンを土砂に より盛立てを行うゾーニングとし、 現地発生土を有効に活用した盛土 構造としているが、土砂材料が自 然含水比約 $30 〜 80 \%$ の軟弱な高 含水比粘性土であったことから、 人工水平排水材を用いて土砂ゾー ンの圧密促進を図りつつ盛立を行

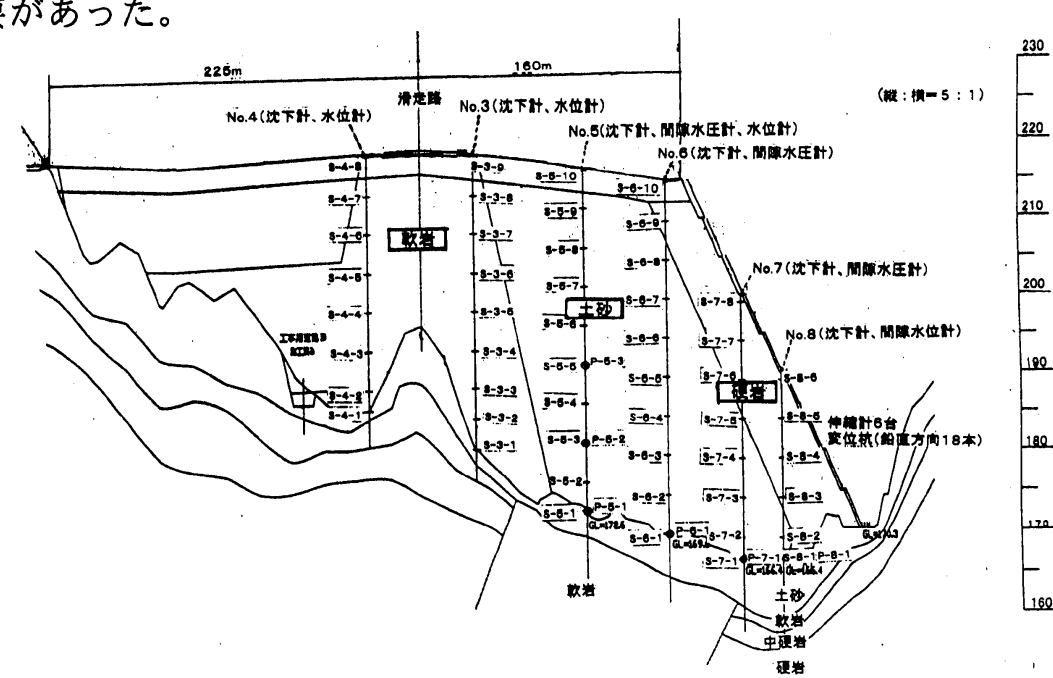

図 1 能登空港本体盛土標淮断面図 
う計画とした。盛土材料の粒度特性を図 2 に示す。 実施設計では、バロンの圧密理論を用いて排水 材敷設による圧密特性を評価し1、円弧すべり法に よる安定検討の結果、鉛直 $5 \mathrm{~m}$ ピッチ・水平 $2 \mathrm{~m}$ ピッチの千鳥配置敷設で所要の安全率を確保する 結果を得た。しかしながら、本工事が高含水比粘 性土の大規模・急速施工であり、また設計段階で は人工水平排水材の効果算定に不確定な部分も多 いことから、本体工事に先立って試験盛土を構築

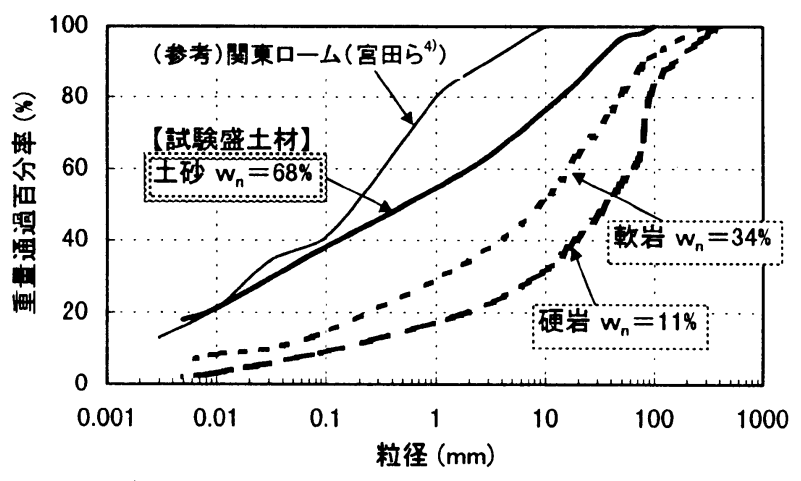

図 2 能登空港盛土材料の粒度特性

し、動態観測による挙動把握・排水効果の確認・品質管理手法の確立等を行うこととなった。そして、 この試験盛土を対象として FEM 解析を実施し、解析モデルの妥当性の検討、および物性パラメータ のキャリブレーションを行った後、本体盛土の解析を実施してその安定性を検討することとした。

\section{3.人工水平排水材を用いた能登空港試験盛土の挙動解析}

\section{1 解析モデルの概要}

(1) 解析モテル

用いた解析手法は、Biot の圧密理論に基づく土/水連成効果を考虑した 2 次元弾粘塑性 FEM 解析 であり、構成則には関口・太田モデルを用いた。試験盛土断面と各種計測器の配置を図 3、また解析

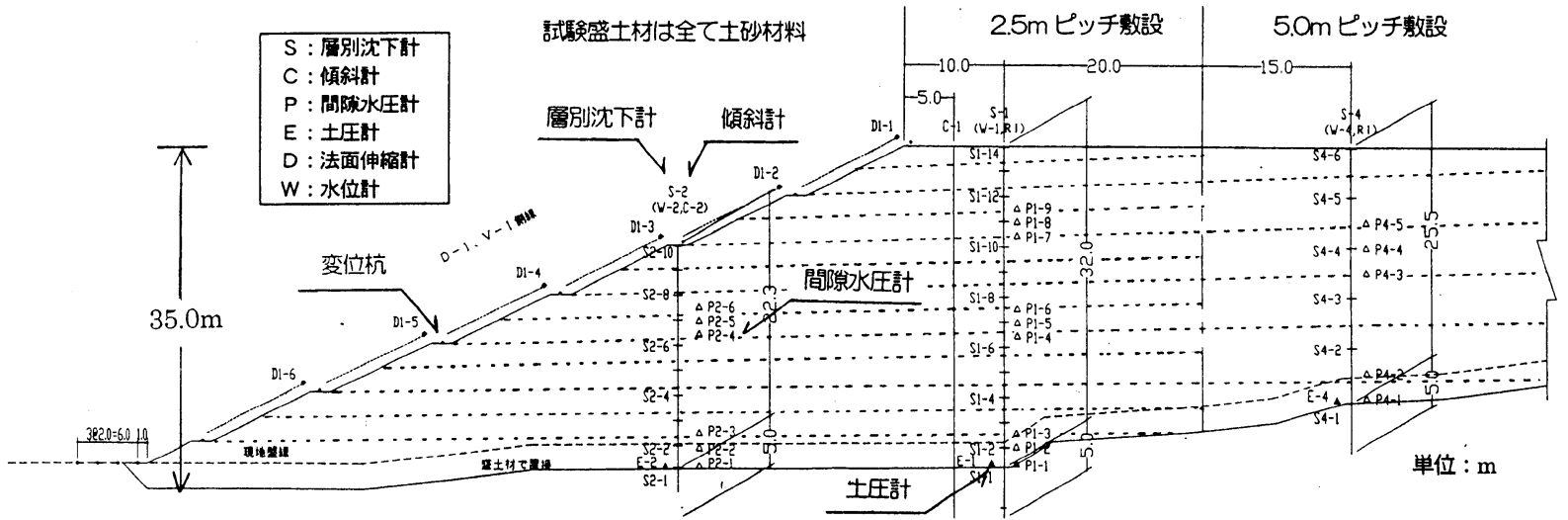

図 3 試験盛土断面図と計測器配置図

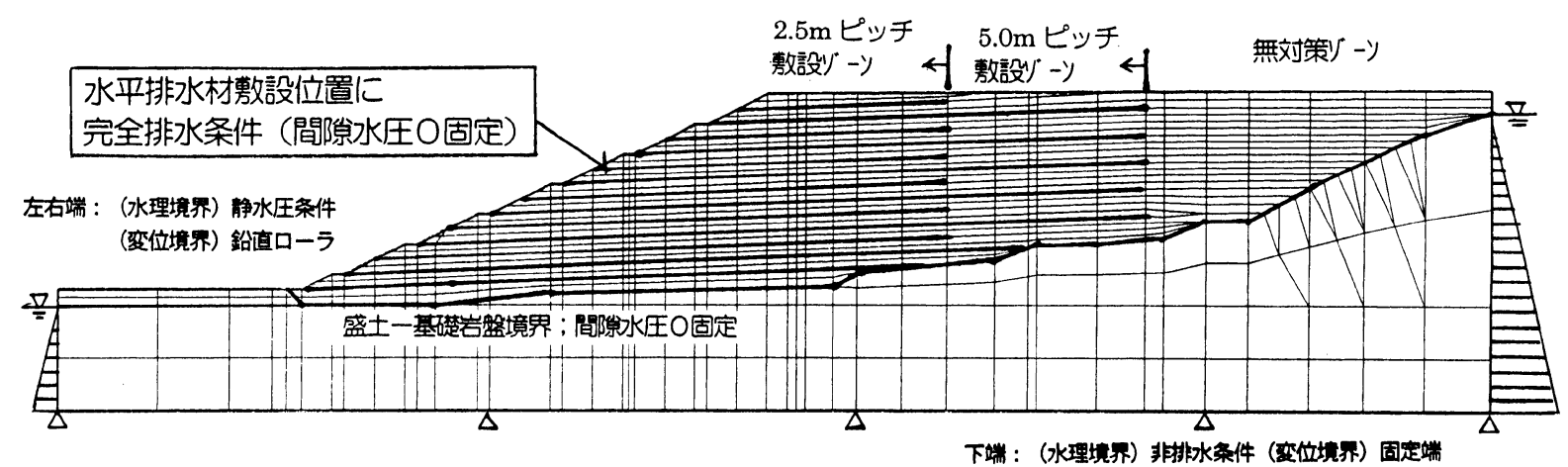

図4 試験盛士のFEM 解析モデル 
に用いたメッシュ図および境界条件を図 4 に示す。 試験盛土とはいえ、盛土高さは最大 $35 \mathrm{~m}$ となって おり、実盛土規模の挙動が観測可能である。なお、 試験盛土では排水材ピッチによる効果の違いを検 証するため、鉛直方向ピッチが $2.5 \mathrm{~m}$ および $5 \mathrm{~m}$ の ゾーンを設けている。

FEM 解析では実際の盛立工程（図 5）に合わせ

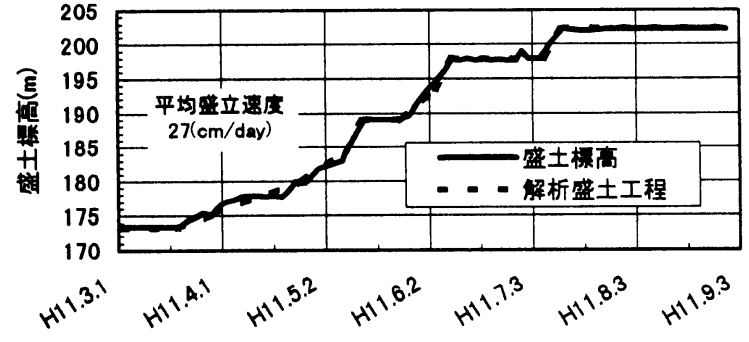

図 5 試験盛土の盛立工程

て要素を逐次追加していくことで、盛立による自重增加とこれに起因する変形過程を表現している。

(2) 水平排水材のモテル化

人工水平排水材の厚さは約 $3 \mathrm{~mm}$ しかないため、これを解析メッシュの一要素としてモデル化する のは非現実的である。そこで、水平排水材は排水効果のみを有すると仮定し、排水材位置の節点に水 理境界条件として完全排水条件（間隙水圧＝0）を付与することにより、その排水効果を表現するこ ととした（図 3 参照）。しかしながら、

(a) 2 次元平面ひずみ解析では奥行き方向に理想的な排水面が広がると仮定してしまうことになるが、

実際は水平方向にも $2 \mathrm{~m}$ ピッチの千鳥配置敷設であることの影響

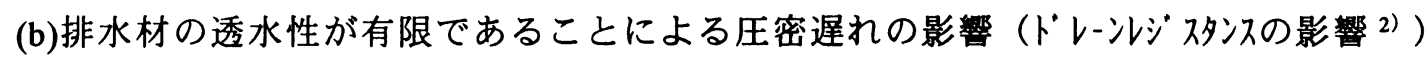

(c)実際の人工排水材は、盛土上載圧によるつぶれや目詰まりによって透水能力が低下する影響 が生じ、完全排水条件のモデル化では排水効果を 過大評価してしまうことが考えられる。

例えば(b)のドレーントジ ス多スについては、宮田ら ${ }^{2)}$ が解析的検討および実測データ整理によって、図 6 に示すようにドレーンレジ ス夕ンス係数 DRa>10-1 であ るとき、施工完了時に盛土深部に間隙水圧が残留 し、排水材が理想的に機能しないことを示してい るが、本試験盛土の条件では $\mathrm{DRa}=0.509$ となり、 理想排水条件にならない範囲に当てはまる。

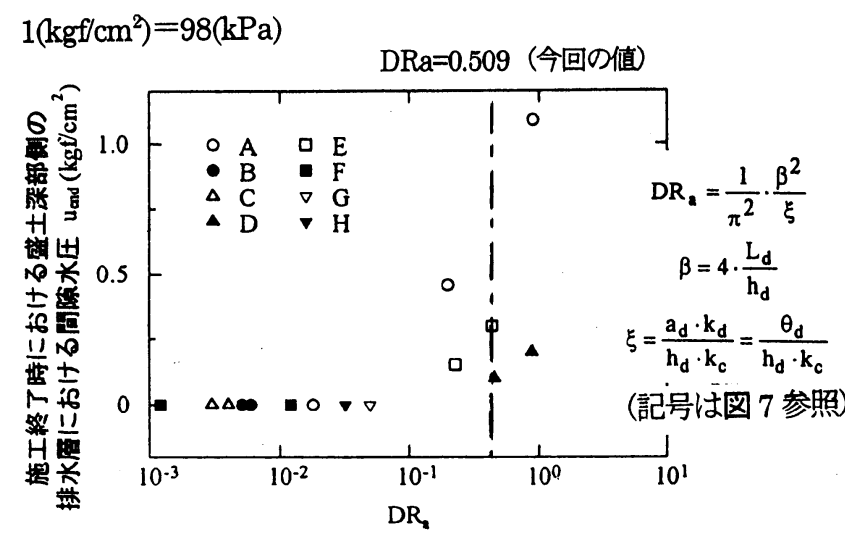

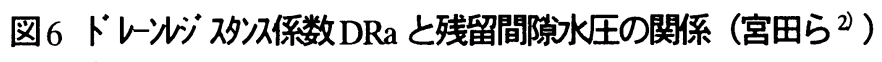

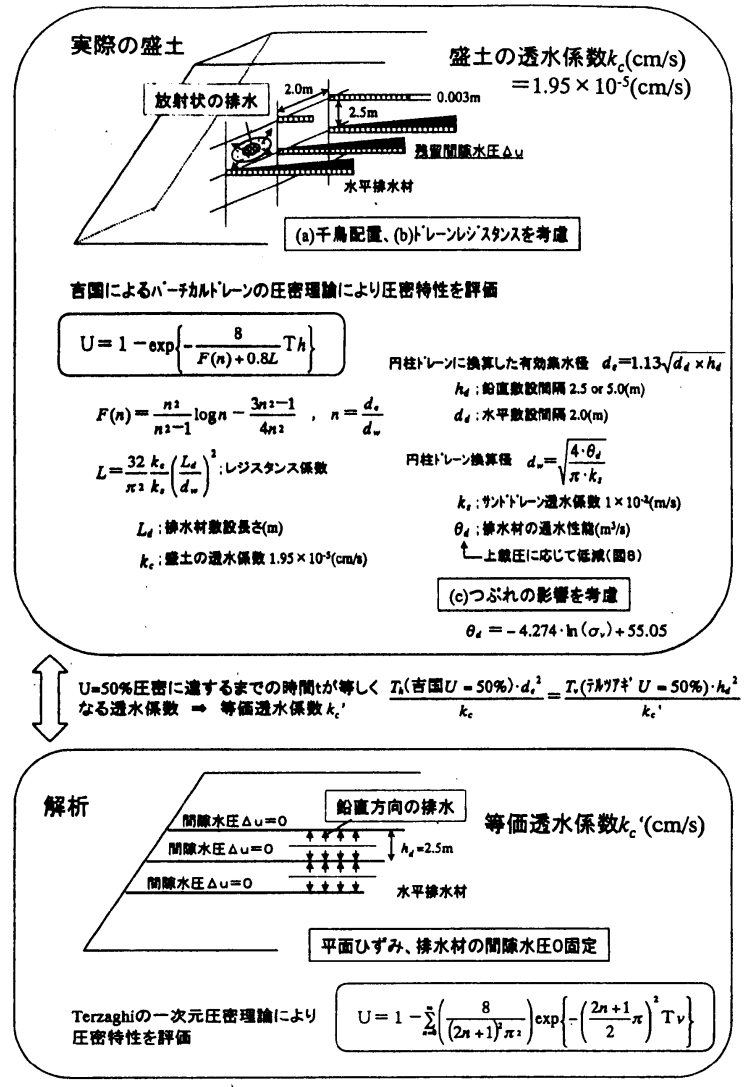

図7 等価透水係数設定の考え方 
そこで、この排水特性の過大評価を避けるために、 排水材間の土の透水係数を上記 $(a) \sim(c)$ の影響を考 慮して実際より低下させて与えることによって、実 状と等価な排水特性を表現することとした。

(a)〜 (c)の影響を考慮した等価透水係数の設定の 考え方を図 7 に示す。実際盛土では千鳥配置および ドレーンレジスタンスを考慮できる吉国の圧密理論 式 ${ }^{3)}$ に、解析断面では排水材に向かう鉛直 1 次元流 れが卓越するとして Terzaghi の圧密理論式に従うと 仮定し、両圧密理論式により評価した平均圧密度 $50 \%$ に達するまでの時間 $\mathrm{t}$ が等しくなる透水倸数をもって、解析側における排水材間の土の透水係数 を設定した。さらにこの吉国の圧密理論式中において、ドレーンの通水性能 $\theta_{\mathrm{d}}$ を図 8 に示す実験式に より上載圧依存を考慮して評価するものとし、盛立の進渉過程に応じて適宜盛土内各部の通水性能を 評価している。これにより、例えば盛土の奥かつ深部ほど、ドレーンレジスタンスと上載荷重による 影響で排水材の通水性能が低下する、といった現象を解析的に表現することができる。また、目詰ま りによる通水性能の低下については、室内目詰まり試験の結果、盛立施工期間内（約 120 日）程度で は有意な通水性能低下が認められなかったため考慮していない。

(3) 物性パラメータ

物性パラメータの一覧 を表 1 に示す。試験盛土 材料に対して行われた各 種室内試験（圧密試験、 長期圧密試験、CU 試験） および現場透水試験の結 果を参照して全ての物性 パラメータを設定してい る。

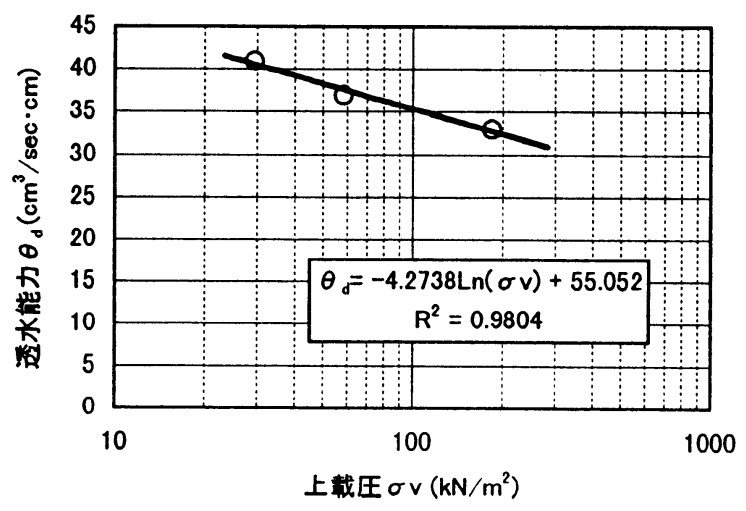

図 8 上載圧と排水材の透水能力の関係
表1 FEM解析に用いた物性パラメータ

\begin{tabular}{|c|c|c|c|c|}
\hline \multicolumn{2}{|c|}{ 弹粘望性パラメータ } & \multicolumn{2}{|c|}{ 段定值 } & \multirow[t]{2}{*}{ 钤定根继 } \\
\hline 単位体積垔量 & $r_{t}$ & 15.5 & $\left(\mathrm{kN} / \mathrm{m}^{3}\right)$ & \\
\hline 先行時の問隔比 & $e_{0}$ & 2.208 & & 室内压密試駺 \\
\hline 压樎指数 & $\lambda$ & 0.2713 & & 室内压䨞拭駺 \\
\hline 㱆洞指数 & $\kappa$ & 0.0486 & & 室内压密侙駼 \\
\hline 压密降伏応力 & $\sigma v_{0}^{\prime}$ & 62.7 & $\left(\mathrm{kN} / \mathrm{m}^{2}\right)$ & 空内压密試殹 \\
\hline 初期の鉛直有効応力 & $\sigma \mathrm{vi}^{\prime}$ & 38.7 & $\left(\mathrm{kN} / \mathrm{m}^{2}\right)$ & 1stage追加要来厚5.0mの要素中心站直応力 \\
\hline 過厓密比 & OCR & 1.62 & & $O C R=\sigma v_{0}^{\prime} / \sigma v_{i}^{\prime}$ \\
\hline 先行時の静止土圧係数 & $\mathrm{K}_{0}$ & 0.59 & & $I_{p}=35.3 \%$ から $K_{0}=0.44+0.42 \times 10^{-2} \mathrm{Ip}$ (Massarsch) より推定 \\
\hline 原位置䊉止土压係数 & $\mathrm{K}_{\mathrm{i}}$ & 0.69 & & IpとOCRから $K_{i}=K_{0}(O C R)^{0540 \times(-10 / 122)}($ Alpan $) 1$ より推定 \\
\hline 有効ポアソン比 & $\nu^{\prime}$ & 0.37 & & $\nu^{\prime}=\mathrm{K}_{0} /\left(1+\mathrm{K}_{0}\right)$ \\
\hline 限界応力比 & $M$ & 1.21 & & CU代験の $\phi^{\prime}=30.2$ 度から $M=6 \sin \phi^{\prime} /\left(3-\sin \phi^{\prime}\right)$ より算出 \\
\hline 透水係数 & $k$ & $1.95 \times 10^{-5}$ & $(\mathrm{~cm} / \mathrm{s})$ & 現坥透水試臨 \\
\hline 透水係数の変化车 & $\omega$ & 8.03 & & 室内压密試験各虍荷段階での透水係数变化 \\
\hline 二次圧樎指数 & $\alpha$ & $3.52 \mathrm{E}-04$ & & 長期压密試駖（90日蛲荷） \\
\hline 初期体積ひずみ速度 & $v_{0}$ & $2.94 \mathrm{E}-06$ & & $v_{0}=\alpha / t_{90}\left(t_{90}: 90 \times\right.$ 压密日数) \\
\hline
\end{tabular}

\section{2 弾粘塑性圧密 FEM による試験盛土の挙動解析結果}

(1) 間隙水圧

図 9 に解析により求められた盛土完成時の間隙水圧コンターを示す。上載圧が大きく、かつドレー ンレジスタンスが最も大きくなる盛土深部にて、排水材間の間隙水圧が大きい結果となっている。ち なみに、人工水平排水材を設定せず、原土をそのまま盛り立てた場合を計算すると、間隙水圧コンタ 一は図 10 の様になる。盛土内部に目玉状に大きな間隙水圧が発生し、また図 11 の Mohl-Coulomb 基 準に基づく破壊域コンターでは盛土斜面部に破壊ゾーンが連続して発生しており、人工排水材を用い なければ盛立不可能であったことが解析結果からも示される。 

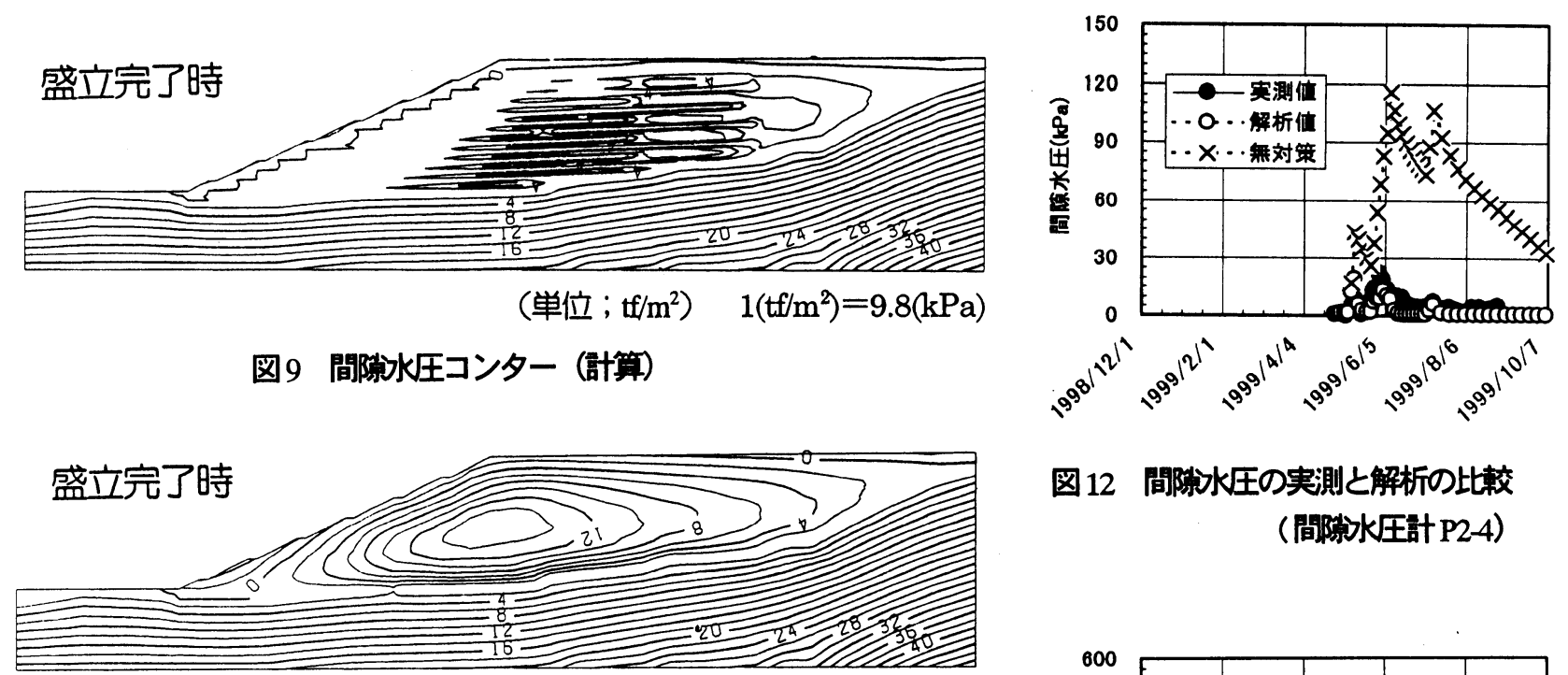

\section{图 12 間陆水圧の実測之解析の比較} （間际水压計 P2-4）

(単位; $\left.\mathrm{t} / \mathrm{m}^{2}\right) \quad 1\left(\mathrm{tf} / \mathrm{m}^{2}\right)=9.8(\mathrm{kPa})$

图10 排水材を數設しない蝪合の間院水圧コンター（計算）
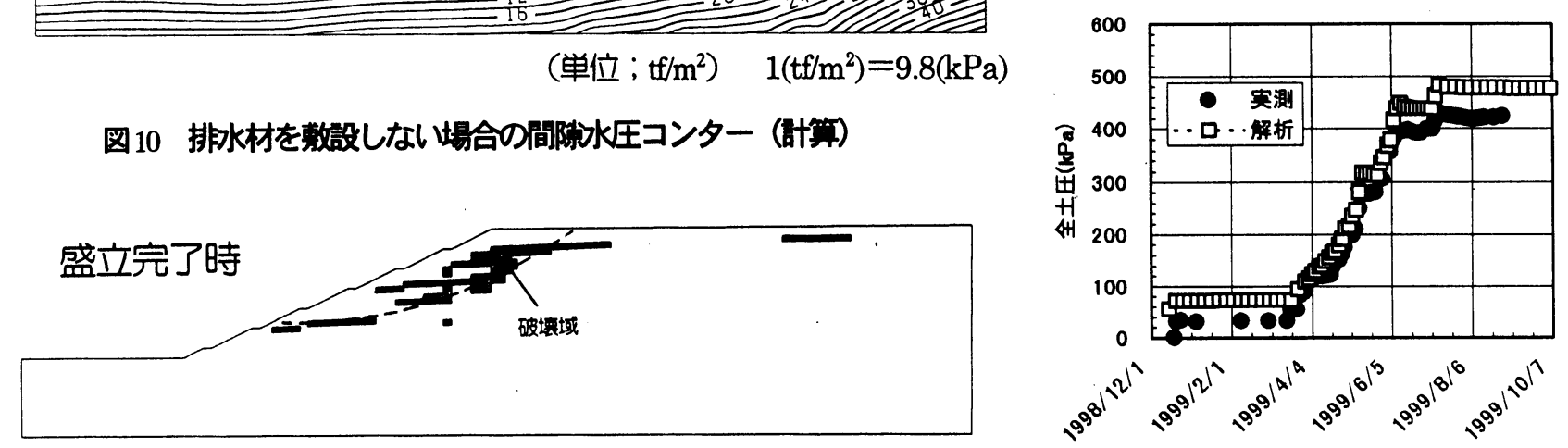

図11 排水材を軗設しない場合の破偯域コンター

図13 鉛亩土圧の実測と解析の比校（土圧計E-1）

図 12 に排水材間に設置された間隙水圧計における実測值と解析值の時系列を比較した一例を示す （参考のため排水材なしの解析結果も併記した）。図 12 より、解析値と実測值は比較的良好な一致を 示しており、等価透水係数の設定が妥当であったことがわかる。

(2) 土圧

図 13 に鉛直土圧（全応力）の実測值と解析值を比較した一例を示す。盛立の進渉にともなう土圧の 増加が解析により良好に再現されていることがわかる。

(3) 沈下

図 14 に層別沈下計による盛土沈下量の実測值と解析値を示す。これより、解析值と実測值は良好に 整合していることがわかる。

(4) 水平変位

図 15 に法肩に設けられた測量杭による法面の沈下・水平変位（変位ベクトル）と、それに対する解 析值の比較を示す。これをみると、解析による法肩の変形はほぼ法面勾配（1：2）に沿った方向に 変位しているのに対し、実測の変形は盛立初期こそ同様な傾向を示すものの、ある時点以降は水平変 位がほとんど生じず、沈下のみが発生していることがわかる。

図 16 に傾斜計による水平変位の実測と解析の比較結果を示すが、傾斜計においても同様に解析によ る水平変位が実測より 2 倍以上大きめに評価されていることがわかる。 

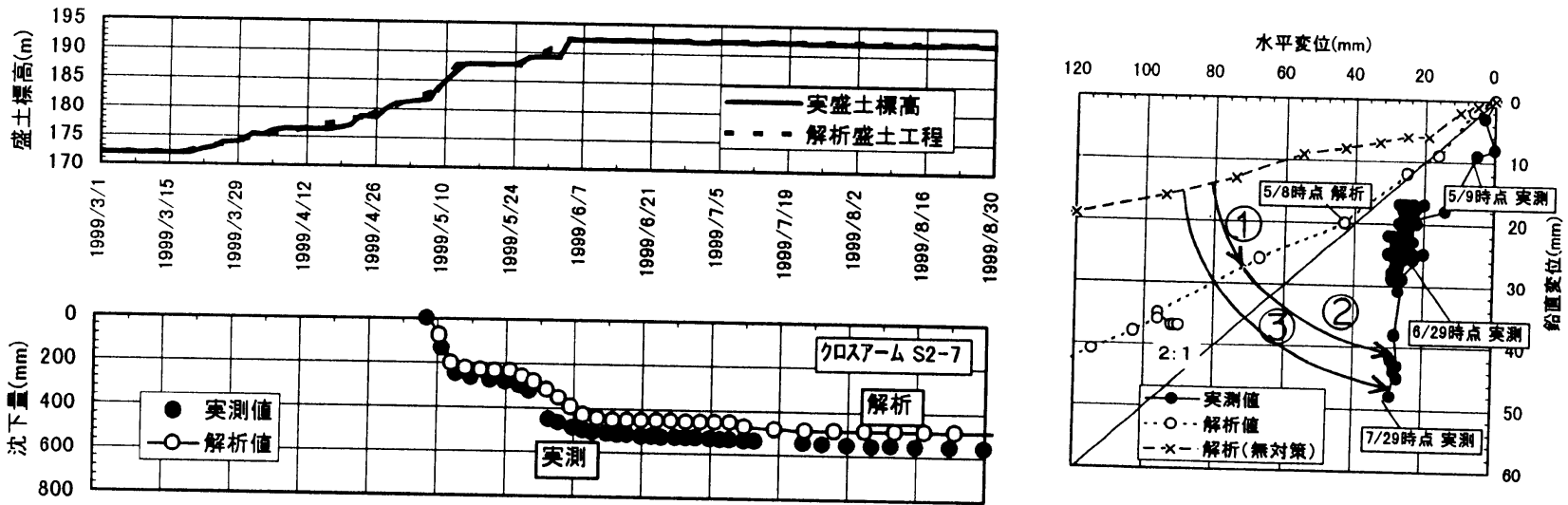

(a) 2 段目小段
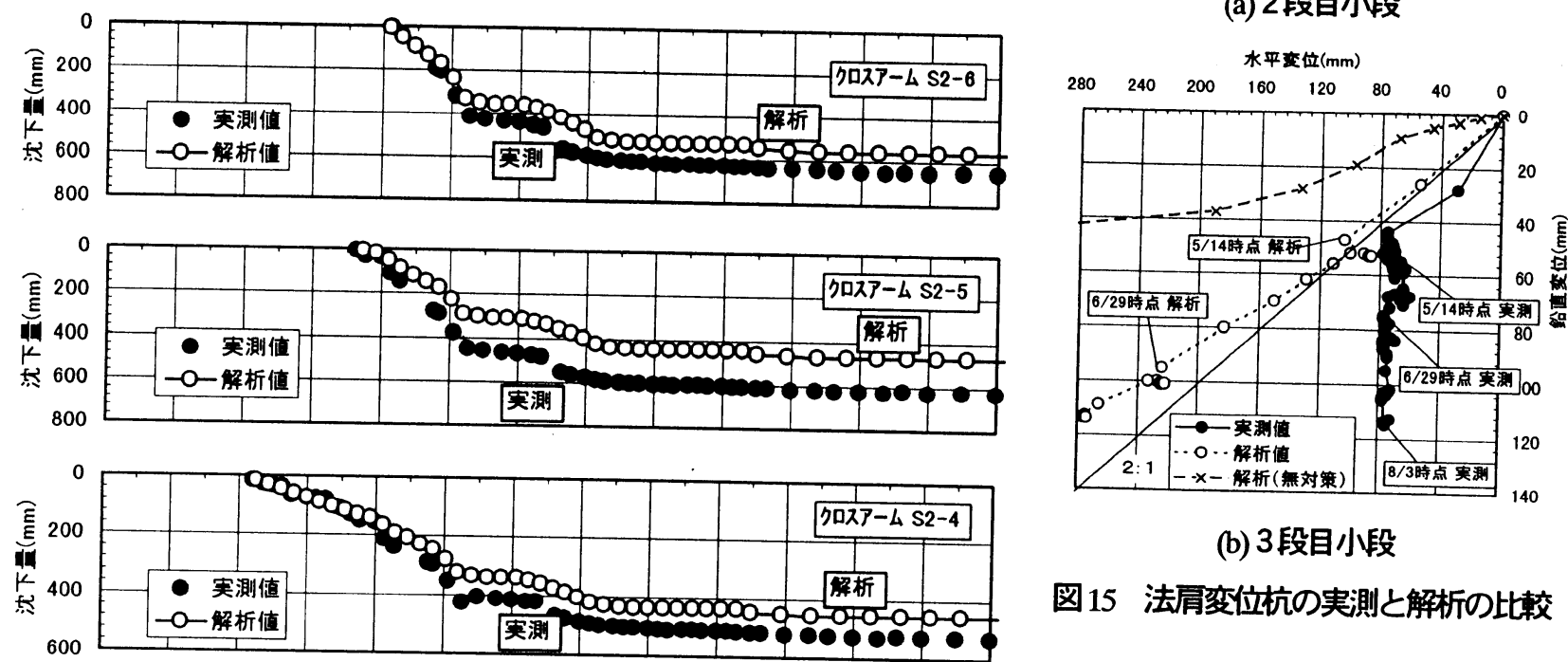

(b) 3 段目小段

図 15 法肩变位杭の実測と解析の比較
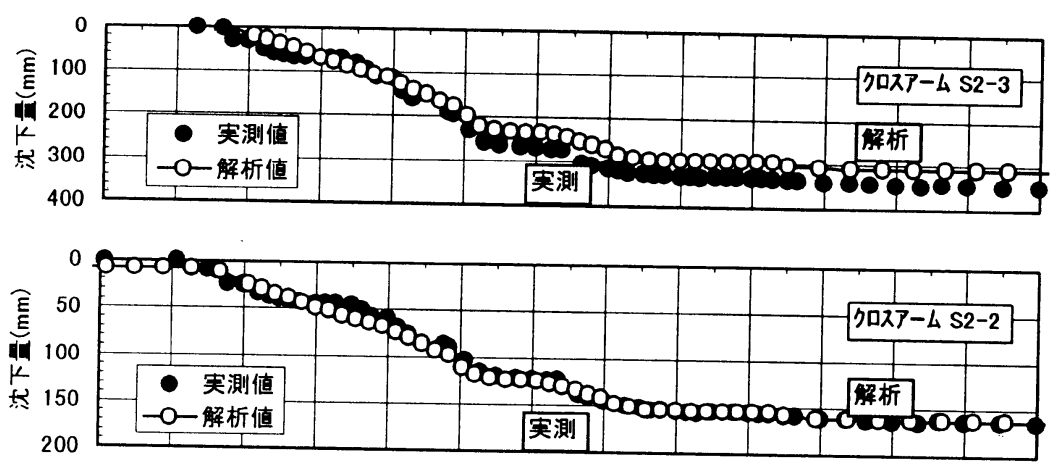

図 14 層別沈下計の実測と解析の比較 (吅不一-4 S2)

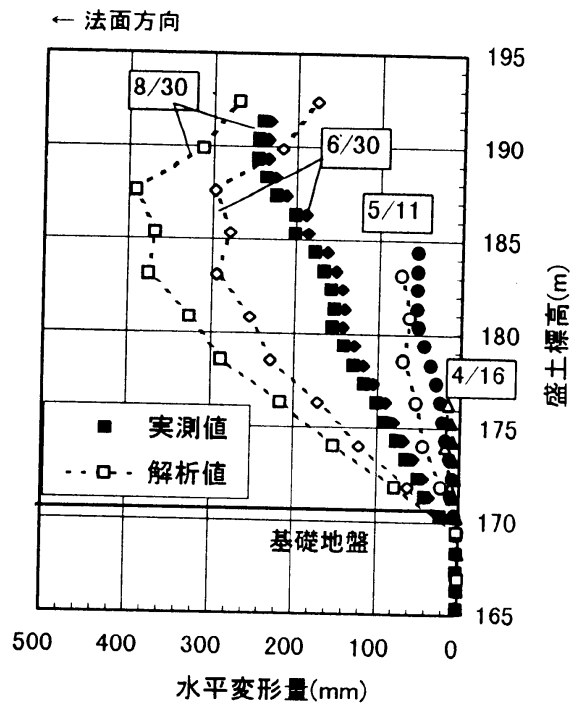

このように実測された盛土の水平変位が解析によ る予測値よりも小さくなる理由として、FEM 解析に 考慮していない排水材と土の摩擦による補強効果が

図 16 傾斜押十の実測と解析の比較（傾斜計 C-2） 実際には発揮され、盛土の水平変位が抑制された可能性が考えられる。

今回試験盛土に供用された排水材は、近年排水・補強の両機能を有するジオテキスタイルとして公 表されているジオコンポジット（高強度・高剛性を有する織布の両面に不織布を貼り合わせた複合ジ 
オテキスタイル）とほぼ同様の構造を有するもの である。宮田ら怆、能登空港試験盛土材料と関東 ロームに対してジオコンポジットの引抜き試験を 行っている。これにより宮田らは、能登空港盛土 材料（土砂）は比較的砂分が多く（図2参照）、 せん断時に正のダイレタンシーを示す材料であり、 引抜き時に正のダイレタンシー効果により強い拘 束力を示す結果、引抜き抵抗力が関東ロームのそ れよりはるかに大きくなることを示している（図 17）。この実験結果より、盛土の側方変位に対し て排水材と土との間に強い拘束効果に起因する引

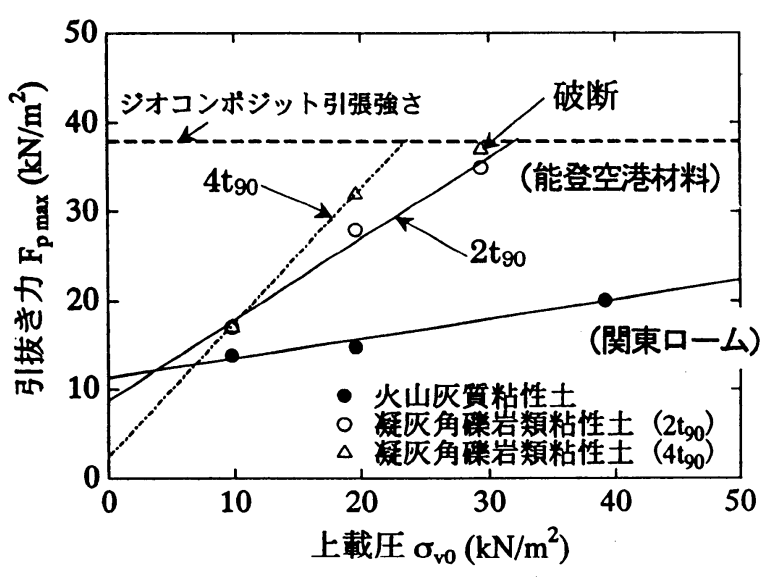

図 17 能登材料之関東口ームの引抜き抵抗力の比较 (宮田ら4)に加筆) 張り抵抗が実際には発揮され、水平変位を抑制したことが考えられる。

前出図 15 の法局変位ベクトル図には、排水材を敷設していない場合の計算結果（×プロット）を併 記している。これより、何の対策もなく原土をそのまま盛立てる場合に対し、(1)が排水による補強効 果、(2)が摩擦による補強効果、そして(3)（=(1)+(2)）が人工水平排水材を敷設したことにより本盛土 に導入された補強効果、と解釈することができるだろう。排水効果のみを考慮する本解析手法では水 平変位を過大評価することになるが、安全側の評価であること、関東ロームなどの負のダイレタンシ 一を示す材料ではさほど過大評価にはならない可能性があること、また空港盛土では沈下特性が特に 重要であることから、実用上の適用に問題はないと判断している。

\section{4.人工水平排水材の敷設効果に関する試計算例}

水平排水材を敷設した盛土の安定性は、排水材の性能や敷設間隔だけで決まるものではなく、盛土 規模やゾーニング、盛立工程（盛立速度や休止期間の存在）、盛土材の物性など、様々な現場条件が これを左右する。現行の設計指針)では、これらを詳細に考虑した設計は不可能に近いが、前章で述べ た弾粘塑性 FEM 解析では、複雑な現場条件を再現することが可能となる。試験盛土に対する解析の 結果、実測值が良好に再現されたことからその適用性は示されたと判断し、以下では能登空港本体盛 土をモデルとして、その適用事例を示す。

能登空港本体盛土は、前出した図1に示すようなソーニングで構成される。土砂ソーンには試験盛土 と同じ水平排水材が敷設され、斜面部には剛性の高い押さえロックが配置されている。実工事では、 当初予測していたよりも降雨日数（施工不能日数）が少なかったために、1 日あたり $30 \mathrm{~cm} 〜 50 \mathrm{~cm}$ の速 度で盛土が行われたが、例年の降雨日数であれば、より急速な盛土を行わざるを得なくなる可能性が あった。この実工程を再現した解析結果と実測挙動の比較結果は、試験盛土と同様に良好に整合して いた（解析が水平変位を過大評価することも同様に生じた）。また解析の結果、本体盛土には破壊領 域は全く発生せず、事実、本盛土は十分な安定性を保ったまま無事建造された。これら本体盛土の実 測值の再現性に対する考察は前章と同様の議論になるので省略し、ここでは次のような試計算を紹介 しよう。 
降雨による施工不能日数が増え、よ り急速な盛土を行わざるを得なかっ た場合、盛土の安定性はどう変化した と考えられるのか。図18にその結果を 示す。盛土速度を日 $30 \mathrm{~cm}$ から日 $1 \mathrm{~m} ま$ で変化させた場合の盛土の安定性を、 局所安全率コンターとして示してい る。盛立て速度が 3 倍以上の日 $1 \mathrm{~m} に な$ っても、不安定なゾーンの発生は全く 見られない。排水材を敷設しておけば、 突発的な急速盛土にも十分に耐えら れることが判る。水平排水材なしのケ ースについて、同様の計算を行った結 果が図19である。日50cmの盛立て速度 で盛土内部に不安定領域 (局所安全率 $\mathrm{Fs}<1.0$ のゾーン) が拡がり始め、日 $1 \mathrm{~m}$ では盛土の完全崩壊を予感させる。実 施工の最大盛土速度が日 $50 \mathrm{~cm}$ にん でいたこと、施工条件の悪化の可能性 等を勘案すると、今回の水平排水材の 敷設が合理的であったことを本結果 は示している。図19は、日 $30 \mathrm{~cm}$ の盛立 て速度が確保される現場条件下では、 水平排水材の敷設は不要となること を物語っているが、例えば、同じ盛立 て速度でも斜面の押えロックがなけ れば、図20のような結果が現れる。押 さえロックは盛土の安定性に大きく 寄与し、これがなければ、この盛土は 日 $5 \mathrm{~cm}$ 以下の緩速な施工を要求される ことになる。

最後に、本盛土の排水材敷設条件で、 盛立材料が関東ローム相当の低い透 水係数 $\left(10^{-7}(\mathrm{~cm} / \mathrm{sec})\right.$ オーダー) であ.つ た場合の計算結果を図21に示す。図18 と同じ敷設条件であっても、原土の透

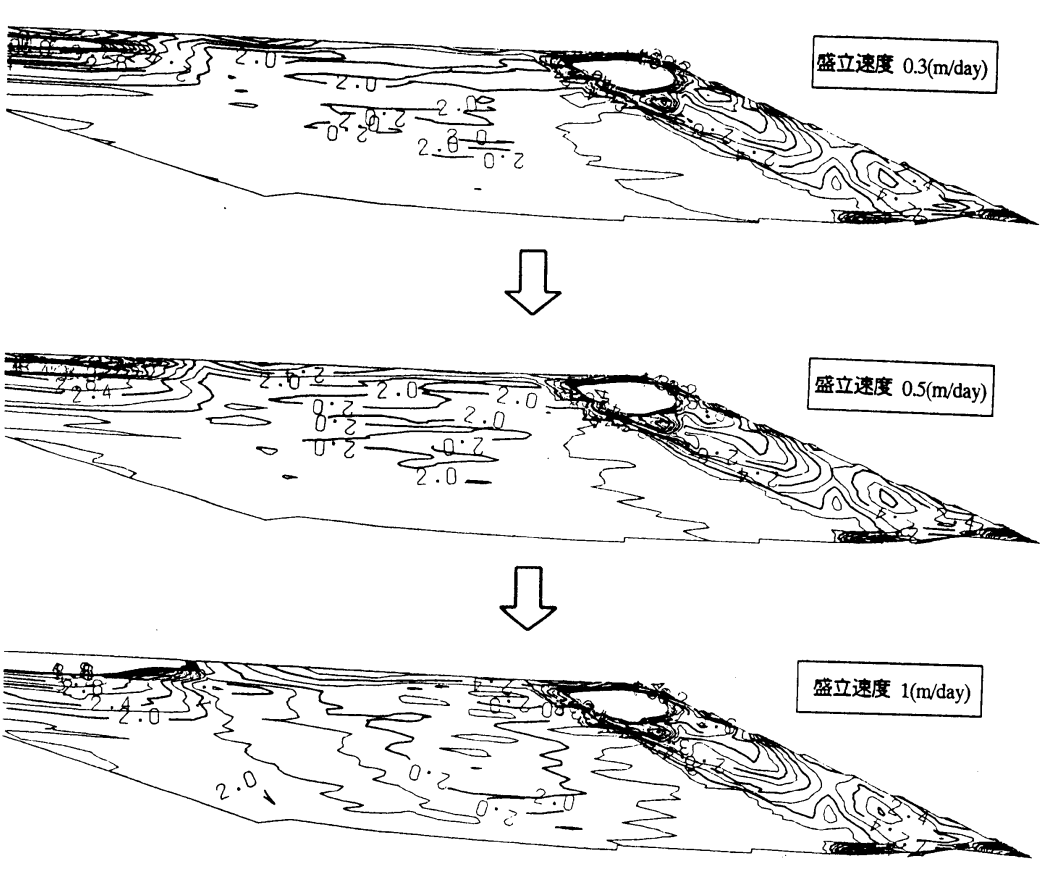

図18 盛立速度を変化させた局所安全率コンター（排水材あり）
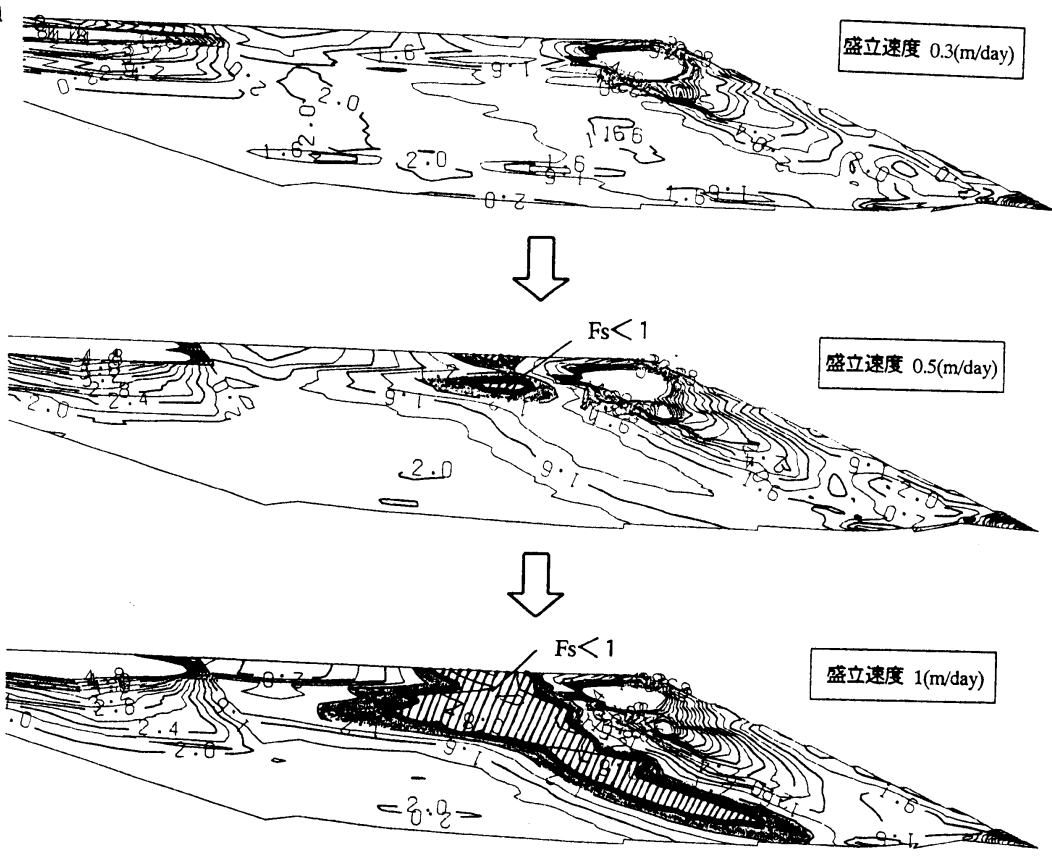

図 19 盛立速度を変化させた局所安全率コンター（排水材なし）

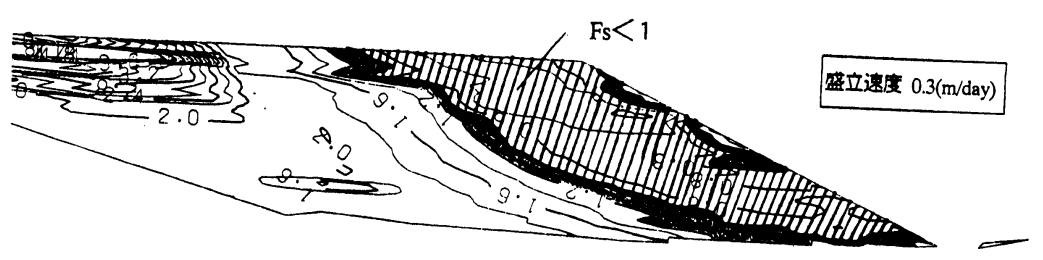

図20 法面硬岩かない場合の局所安全率コンター（排水材なし） 
水性が低ければ日 $50 \mathrm{~cm}$ の盛立て速度 で不安定領域が現れてしまう。特に、 宮田らの実験結果4)（図17）方ら、関 東ロームでは摩擦による補強効果が あまり期待できないことを勘案すれ ば、このような不安定領域の発生は即 盛土の有意な変状に直結する可能性 が高い。この条件では、より密な排水 材配置が必要となってくることが明 らかである。

以上のように、水平排水材の必要性
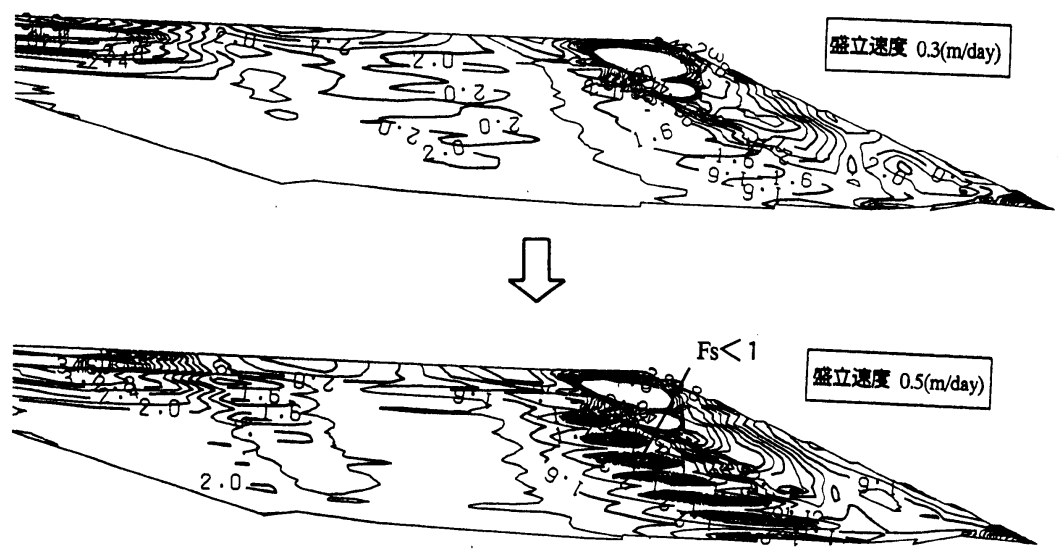

図21盛士材透水佂数 $1.95 \times 10^{7}(\mathrm{~cm} / \mathrm{s})$ の場合の局所安全率コンター (排水材あり) や所要敷設間隔は、盛土規模やソー二 ング、盛立工程、原盛土材の物性など、幾つかの現場条件の組み合わせによって大きく変化する。今 回、実規模盛土において適用性の検証を試みた弾粘塑性FEM解析手法は、今後、水平排水材のより合 理的な設計を行っていくうえで、有用なツールとなる可能性を有している。

\section{5. まとめ}

本論文では、人工水平排水材を用いた高含水比盛土の応力変形挙動解析手法の確立を目指し、関口・ 太田モデルを構成則とした弾粘塑性 FEM 解析の適用を試みたものである。特に人工水平排水材のモ デル化においては、水平排水材の千鳥配置・ドレーンレジスタンス・上載圧によるつぶれの影響を考 慮し、より現実に近い排水条件を表現することに留意した。この結果、試験盛土および本体盛土とも、 間隙水圧・土圧・沈下挙動は寒測值と良好に整合し、今回用いた解析手法が人工水平排水材を敷設し た盛土の応力変形予測手法として概ね妥当であることが示された。ただし、実盛土の水平変位はほと んど生じず、解析には見込まれていない土と排水材の摩擦による補強効果が実際には発揮されている 可能性があることがわかった。

また、能登空港造成盛土を対象として、盛立施工速度や盛土材透水係数などの現場条件の組み合わ せによって盛土安定性が大きく変化することを試計算により示し、現場毎の材料特性や施工条件、境 界条件等を詳細に反映できる FEM を用いた合理的な水平排水材の敷設設計の可能性を示した。

参考文献：

1) 土木研究センター : ジオテキスタイルを用いた補強土の設計・施エマニュアル, pp.82-91, 1993.

2) 宮田喜壽・木暮敬二・落合英俊 : 高含水比粘性土盛土における水平排水層の排水効果の評価法, 土 木学会論文集 No.589／III-42,pp.121-129，1998.

3）吉国 洋：バーチカルドレーン工法の設計と施工管理，技報堂，pp.29-49, 1979.

4) 宮田喜壽・末次大輔・木暮敬二 : 粘性土のダイレイタンシー特性がジオコンポジットの引抜き抵抗 特性に及ぼす影響，第 15 回ジオシンセティックスシンポジウム（投稿中），2000. 